\title{
Development of Learning Media for Video Audio-Visual Stop Motion Based on Contextual Teaching and Learning in Science Learning Water Cycle Material
}

\author{
*Ismah Mufidah1, Lukman Nulhakim², Trian Pamungkas Alamsyah ${ }^{3}$ \\ 1,2,3 Program Studi Pendidikan Guru Sekolah Dasar. Universitas Muria Kudus, Kudus, Indonesia
}

\author{
A R T I C L E I N F O \\ Article history: \\ 1 Mei 2020 Received in \\ revised form \\ 11 Juni 2020 \\ Accepted 10 Juli 2020 \\ Available online 25 Agustus \\ 2020 \\ Kata Kunci: \\ Stop motion, contextual \\ teaching and learning, siklus \\ air \\ Keywords: \\ Stop motion, contextual \\ teaching and learning, \\ water cycle
}

\begin{abstract}
A B S T R A K
Pembelajaran yang dilakukan secara konvensional seringkali membuat siswa jenuh dan kurang termotivasi untuk belajar. Di masa pandemi ini penggunaan media berbasis teknologi seperti video pembelajaran audio-visual dapat menjadi satu diantara cara bagi guru untuk menciptakan pembelajaran yang efektif. Tujuan dari penelitian ini adalah untuk mengetahui prosedur pengembangan dan kelayakan media pembelajaran video audio-visual stop motion berbasis contextual teaching and learning. Penelitian ini menggunakan desain penelitian dan pengembangan. Data diperoleh dengan menggunakan angket, dokumentasi dan google form. Pengembangan media video audiovisual stops motion berbasis Contextual teaching and learning dapat menjadikan pembelajaran daring di masa pandemi menjadi lebih efektif, dan efisien serta layak digunakan di sekolah dasar.
\end{abstract}

\section{A B S T R A C T}

Learning done conventionally often makes students bored and less motivated to learn. In this time of the pandemic, the use of technology-based media such as audio-visual learning videos can become one of the ways for teachers to create effective learning. Audio-visual learning media are developed to make it easier for teachers to deliver learning materials. By developing technology-based media, online learning can be accomplished. The purpose of this research is to know the development and feasibility of media learning audio-visual video stop motion based contextual teaching and learning. The study employs research design and development. The development of audio-visual media videos stops motion based contextual teaching and learning is expected to make online learning during the pandemic more effective, efficient, and useful in elementary school.

\section{Introduction}

The current positive case for Covid-19 is dated August 9, 2020, according to the Ministry of Health, which was conveyed through the Covid-19 Task Force on the www.covid19.go.id page, there were an additional 1898 confirmed positive cases of the Coronavirus with a total of 125,396 positive cases in Indonesia. This causes all the habits of community activities to begin to change. The community must start limiting social interactions or what is known as Social Distancing during activities outside the home. Not only that, but these changes also apply in the world of education, especially in the implementation of learning activities.

The government's decision to move the learning process in accordance with Circular Number 36962 / MPK.A / HK / 2020 so that all teaching and learning activities both at schools and college campuses use online methods (online), confusing many parties. School unpreparedness in doing online learning is a major factor in the difficulties faced. Another impact that is an obstacle for schools to Covid-

Copyright (c) Universitas Pendidikan Ganesha. All rights reserved 
19 is the low mastery of technology, limited facilities, and infrastructure owned by schools, the internet network, and the costs incurred are not small, and the unpreparedness of teachers in implementing online learning.

Based on the results of observations made by giving questionnaires, it was found that there was a problem in SD Muhammadiyah Bojong Nangka that the unpreparedness of schools and teachers was an obstacle to the implementation of online learning. Teachers used to use conventional learning so that when faced with problems that required online learning, schools and teachers had a little difficulty. The facilities and infrastructure at the school are quite good because the school already has computers and internet networks. However, for the Learning Implementation Plan (RPP), instructional media, and online learning evaluation models, teachers and school principals admit that they do not have readiness. During online learning, the teacher only uses the lecture method and provides questions so that during the learning process students become bored, unfocused, and not motivated during learning. Problems that occur are also learning to be unattractive because there is no face to face face to face. In the assessment process, students get less than optimal results, especially in science subjects, one of which is related to the water cycle material. The water cycle is a material that explains how something happens. According to the informants, the water cycle material will not be conveyed properly if it is only presented by the lecture method. This material can be taught using media or through practicum (Kurniawan, 2019). The simplest learning media can be used in explaining water cycle material such as image media so that students can visualize the process in the water cycle (Rozie, 2013).

Based on the description of the problems that occur, efforts or solutions are needed to overcome these problems. One of the efforts that can be done is by developing a learning media. The use of learning media in the learning process is important to use because using learning media can arouse student interest and motivation, reduce verbalism, as a channel of information, encourage students, and increase knowledge retention in learning so that learning is more meaningful (Lisiswanti, 2016; Asyhari, 2016). Learning media that can be developed to help deliver material on the water cycle material is the development of audio-visual video media based on contextual learning for online learning.

Audiovisual media is a learning media that does not only focus on the material, but also pays attention to the senses of students, especially vision and hearing, and uses all existing components in contextual learning so that it can help achieve educational goals. (Purwono, et al, 2014; Hayati, et al, 2017). The use of audio-visual media can attract children's attention to follow the learning process (Fujiyanto, et al, 2016). The advantages of using audio-visual media in learning, namely the messages or material that are conveyed are easy to understand, understand, and retain in memory so that they will have a real effect on learning outcomes in the cognitive, affective and psychomotor domains of students, besides that audio-visual media can also overcome distance and time limitations and can be repeated to increase understanding (Pradilasari, et al, 2019). Thus, learning will be more interesting and meaningful, especially in online learning, which must now be done to minimize the spread of Covid-19. The existence of media that can present both images as well as sound, can help students divert their boredom and will be more interested in taking part in learning that uses multimedia rather than just following conventional learning through lectures conducted by teachers (Maryanti \& Kurniawan, 2017). In particular, the audiovisual media used is the stop motion audiovisual media.

The effectiveness and efficiency of online teaching and learning activities, especially in water cycle materials, can be improved by using stop motion audio-visual video media. Stop motion is a technique of manipulating video motion from a combined image that forms as if a collection of images is like a moving video (Adi, 2017). Stop motion can help teachers visualize the water cycle process with interesting concepts. This video is also designed based on the components of contextual learning, namely, constructivism, finding or inquiry, asking questions, learning societies, modeling, reflecting, and authentic assessment. These components are put together into a video so that the learning process can be more meaningful. In line with a study that learning will be more meaningful if learning is related to what students learn and what they experience directly in real life. That way, students will not only respond to learning that is limited to remembering a concept but a fact that can be useful in the life of students (Sari, P. M. N., et al., 2020). This is in line with previous development research conducted by (Maryanti, 2017), a stop motion animation video learning media developed for biology learning resulted in the conclusion that this media is interesting and very helpful in creating creativity and innovation to facilitate the learning difficulties of students. Based on the explanation above, the learning media developed is audio-visual stop motion video media based on the Contextual Teaching Learning (CTL) learning model.

Contextual Teaching Learning learning model is a learning model with a learning concept that helps teachers to relate the material they teach to the real-world situation of students and encourages students 
to build relationships between their knowledge and its application in their lives as family members and communities so that learning is expected to be more meaningful for students (Kasmawati, et al, 2017; Sabroni, 2017) The knowledge and skills of students are obtained from their efforts to construct their knowledge and new skills when they participate in learning (Sulfemi, 2019). The learning process takes place naturally in the form of student activities to work and observe, students are required to be active, not only to receive knowledge transfer from the teacher (Hakiki, et al, 2016). Integrated with learning media that is more attractive, is expected to have a positive influence on the implementation of learning.

Several researches have been carried out related to the development of stop motion audiovisual learning media. Research conducted by (Maryanti, 2020) shows that the use of stop motion learning media can help facilitate learning difficulties faced. Similar research was also carried out by (Lailatusholihah 2016) which shows that the use of stop motion learning media is very good to use and has a positive impact. The difference between the previous research and this research is that this research is a stop motion audio-visual video development using the basis of contextual teaching and learning or what is commonly called contextual learning. So, these differences are the advantages of this study. The advantage of CTL-based stop motion audio-visual video is that through this video it can convey a material how something happens with an attractive presentation that can make it easier for students to understand the content of the material through contextual learning. Students will develop knowledge and link teaching material in their daily life. Judging from the contextual learning component, this CTL-based stop motion audio-visual video can be used in water cycle material. This is because the water cycle material requires better visualization than just an image so that the delivery of this material can be more easily absorbed by students. Water cycle material can also be linked to daily life so that learning can be more meaningful and contextual.

Therefore, this study is intended to develop audio-visual stop motion video learning media based on contextual teaching and learning in science learning water cycle material for grade 5 elementary schools to research how to develop stop motion video media based on Contextual teaching and learning (CTL). ) for science learning in grade $\mathrm{V}$ elementary schools, the feasibility of stop motion video media based on Contextual teaching and learning (CTL) for science learning in grade V elementary schools, as well as students' responses to Contextual teaching and learning (CTL) based stop motion video media for science learning grade $\mathrm{V}$ elementary school.

\section{Methods}

This research is a type of research development or Research and Development (R\&D). This type of research is a research method used to produce certain products and test the effectiveness of these products (Sugiyono, 2016). According to Sugiyono, there are ten stages of development research, but due to time and cost limitations, this CTL-based stop motion audio-visual video research only reaches the sixth stage, which is limited product testing. The first stage, namely problem analysis to find out problems that exist in school because research must start from a problem. The second stage, namely collecting data employing observation in the form of filling out a questionnaire to informants to find out the problems and needs that exist in the school. The third stage, namely product design by creating a stop motion audiovisual video media based on CTL that can be used as a solution to problems and needs encountered during the preliminary study. The fourth stage is product validation which is useful for determining the feasibility of the CTL-based stop motion audio-visual video media. This product validation was carried out by three teams of experts, namely media experts, material experts, and language experts. The fifth stage, namely product revision which aims to produce a better product so that it is suitable for use. Product revisions are carried out in accordance with the criticism and suggestions of the validation expert team. The sixth stage, the limited trial. The limited trial was conducted at SD Muhammadiyah in grade 5. The limited trial aims to determine the response of students to audio-visual stop motion video media based on CTL.

Data collection techniques in this study used questionnaires, documentation, and google form. Geographies were used to identify needs, find problems, and find out the feasibility of learning videos. Documentation was used to obtain other information available to respondents, in the form of photos or questionnaire results. Google form is used to collect some of the data on product validation results and student responses online.

The instrument in the media expert validation test questionnaire has evaluation criteria, namely the aspect of presentation feasibility and content feasibility aspect (BSNP, 2008). 
Table 1. Media Expert Validation Instruments Table

\begin{tabular}{|c|c|c|}
\hline No & Criteria & Indicators \\
\hline 1 & Presentation Feasibility Aspects & $\begin{array}{l}\text { 1. Match title with material } \\
\text { 2. Video creation process suitability } \\
\text { 3. Compatibility for image quality } \\
\text { 4. Compliance with color design } \\
\text { 5. Compatibility of image blend quality } \\
\text { 6. Compatibility of image interest with the material } \\
\text { 7. Match the size of the text on the video } \\
\text { 8. Conformity to the standard language of the text } \\
\text { 9. Conformity to the unity of meaning in the text } \\
\text { 10. Conformity to communicative language in the text } \\
\text { 11. The suitability of the language used so that it is easy } \\
\text { to understand } \\
\text { 12. Match the clarity of the voice of the narrator/player } \\
\text { 13. Compatibility of the sound of music on video } \\
\text { 14. The appropriate meaning of the music in the video } \\
\text { 15. Compatibility of sound quality in video }\end{array}$ \\
\hline 2 & Content Feasibility Aspects & $\begin{array}{l}\text { 1. The suitability of the flexibility of using video } \\
\text { 2. Video user target suitability } \\
\text { 3. Suitability to the limitations of learning space and } \\
\text { time } \\
\text { 4. Suitability for the substitute role of the teacher in } \\
\text { teaching the Water Cycle material } \\
\text { 5. Conformity to the role of nature helps teachers teach } \\
\text { 6. Suitability to the student's independent learning } \\
\text { function } \\
\text { 7. The suitability of the video finalization to the material } \\
\text { 8. The suitability of the video presentation format } \\
\text { 9. Suitability for the effects of student enthusiasm for } \\
\text { learning } \\
\text { 10. Conformity to the precision of the media on the } \\
\text { material } \\
\text { 11. Appropriateness of target use by teachers and } \\
\text { students } \\
\text { 12. The suitability of the video duration to the student's } \\
\text { concentration level } \\
\text { 13. Conformity convenience and compatibility in } \\
\text { delivering video messages } \\
\text { 14. The suitability of the duration of the video to the level } \\
\text { of student boredom } \\
\text { 15. The suitability of using properties in the video }\end{array}$ \\
\hline
\end{tabular}

The instrument in the material expert test questionnaire has assessment criteria on aspects of content feasibility, presentation feasibility aspects, and contextual assessment aspects (BSNP, 2008).

Table 2. Material Expert Validation Instrument Table

\begin{tabular}{lcll}
\hline No & \multicolumn{1}{c}{ Criteria } & \multicolumn{1}{c}{ Indicator } \\
\hline 1 & Content Feasibility Aspects & 1. & Suitability of material with SK and KD \\
& & 2. & Material accuracy \\
& & 3. & Up-to-date material \\
2 & Presentation Feasibility Aspects & 1. & Encourage desire \\
& & 2. & 2. Presentation technique \\
& 3. & 3. Presentation of Learning \\
\hline
\end{tabular}




\begin{tabular}{lll}
\hline No & \multicolumn{1}{c}{ Criteria } & \multicolumn{1}{c}{ Indicator } \\
\hline \multirow{3}{*}{ Contextual Assessment Aspects } & 4. & 4. Coherence and sequence of thought \\
& 1. & 1. It is contextual \\
& 2. & 2. Contextual Components \\
\hline
\end{tabular}

The instrument in the language expert test questionnaire has assessment criteria on the language experts' aspect (BSNP, 2008).

Table 3. Language Expert Validation Instruments Table

\begin{tabular}{lll}
\hline \multicolumn{1}{c}{ No } & \multicolumn{1}{c}{ Indicator } \\
\hline 1 & The aspect of Language & 1. Straightforward \\
& Eligibility & 2. Communicative \\
& 3. Dialogical and interactive \\
& 4. Conformity with the level of development of students \\
& 5. Cluster and coherence of thought lines \\
& 6. Use of terms, symbols, or icons \\
\hline
\end{tabular}

Whereas the student response questionnaire instrument has assessment criteria, namely the appearance aspect, the material presentation aspect, and the benefit aspect (BSNP, 2008).

Table 4. Table of Student Response Instruments

\begin{tabular}{lll}
\hline No & \multicolumn{1}{c}{ Criteria } & \multicolumn{1}{c}{ Indicator } \\
\hline 1 & Display Aspects & 1. Text clarity \\
& & 2. Clarity of the material \\
& & 3. The beauty of the video \\
& 4. Video and material compatibility \\
& Material & 1. Presentation of material \\
& & 2. Clarity of sentences \\
& Benefits Aspects & 3. Clarity of terms \\
& & 1. Sample suitability with material \\
& & 2. His interest in using CTL-based stop motion audio- \\
& & 3. Increase motivation to learn \\
\hline
\end{tabular}

The data analysis technique was carried out by analyzing the results of the feasibility of the data by expert test assessments and the results of assessing the responses of students using the formula according to Purwanto (Purwanto, 2014). The feasibility of a CTL-based stop motion audio-visual video is determined by interpretation criteria according to Ridwan (Ridwan, 2015).

\section{Finding and Discussion}

Research results on the development of audio-visual stop motion learning media based on CTL were carried out based on Sugiyono's R\&D modification development procedures, namely conducting problem analysis, data collection, product design, product validation, design revision, and product testing (Sugiyono, 2016). This research was conducted at SD Muhammadiyah with the following stages.

The first stage, problem analysis. Problem analysis begins with conducting curriculum analysis, material analysis, and needs analysis. In the curriculum analysis, it was found that SD Muhammadiyah refers to the 2013 curriculum for grade V by identifying KI and KD which are then broken down into indicators. In the material analysis, it was found that the material used was the water cycle material contained in the 2013 curriculum. The basic competencies in this material were 3.8 Analyzing the water cycle and its impact on events on earth and the survival of living things, and indicators 3.8.1 Explaining the stages water cycle, such as evaporation, condensation, and precipitation. The second stage, data collection. After analyzing the problem, data, and information related to the research were found through a need s analysis questionnaire and documentation. Then the data and information are collected. The data and information are then processed according to the needs analysis that has been obtained, namely making 
CTL-based stop motion video learning media. To make the video, you need a collection of materials related to the water cycle. In making stop motion videos based on CTL, initial ideas, concepts, scripts, properties, tools, and materials are needed as support and reference in developing CTL-based stop motion audiovisual video learning media.

The third stage, product design. At this stage, the researcher designs a product in the form of a stop motion learning video based on CTL on the water cycle material that has been adjusted to the basic competencies and indicators that have been determined by compiling in the storyboard. The first step in making a storyboard is to prepare the water cycle material according to the indicators. At this stage of making stop motion videos, the product was carried out and designed using an existing application on a smartphone, namely using the Stop motion Studio application. Each object in the video was made by a researcher who was his work and was photographed using a stop motion technique using the Stop motion Studio application, and a pod to support the process of making a stop motion video. the object created by the researcher is an object related to the water cycle material, such as the sun, clouds, water clumps, water vapor, a location background to support the video layout, and other supporting objects. The photos that have been taken will be rendered for the next process. To add to the appeal, this product is also made using an online video editing application, namely Animker 2.0 Pro. This application is used only in the opening, closing, and which contains a lot of writing so that students can read it more easily. The rendered stop motion video and audio-visual video created in the Animker 2.0 Pro application are then edited for the final process.

After additional objects and animations have been made, it is followed by making a video which includes, opening, part of the content/material, and closing of the CTL-based stop motion video by combining all components both stop motion video and animation video including dubbing, sound effects, and back sound. After making the video, all the components that have gone through the editing process are then rendered to be made into a.MP4 video and can be shared via YouTube, CD, and data storage with a minimum storage space of $2 \mathrm{~GB}$. The opening section contains initial information in the form of self-data from the video maker, class descriptions, a description of the basic competencies and indicators used, the title of the material used, and perceptions before going to the core of the lesson. Researchers made using the Animker 2.0 Pro online editing application for the initial information section and the Stop motion Studio application for the apperception section. The content/material section of this learning video is in accordance with basic competencies 3.8 Analyzing the water cycle and its impact on events on earth and the survival of living things, and indicator 3.8.1. Describe the stages in the water cycle such as evaporation, condensation, and precipitation. In this section, it is made interesting by adding practices that students can do immediately while learning using this video. In this section, the researchers prioritize making videos with stop motion techniques using the Stop Motion Video application. Furthermore, in the closing section, there are conclusions, simple schemes, closing sentences, and evaluation questions.

The fourth stage, product validation. The product that has been designed will be validated by three teams of experts at the fourth stage of this product development to find out its advantages and disadvantages. Among them are two lecturers as media experts, two lecturers as material experts, and two lecturers as language experts.

Table 5. Table of Results of Media Expert Validation Assessment

\begin{tabular}{clccc}
\hline No & Assessment Aspects & Expert Score Media I & Expert Score Media II & NP (\%) Total \\
\hline 1 & Presentation Feasibility Aspects & $95,00 \%$ & $100 \%$ & $97,50 \%$ \\
2 & Content Feasibility Aspects & $91,67 \%$ & $88,33 \%$ & $90,00 \%$ \\
\hline \multicolumn{2}{r}{ Mean } & $\mathbf{9 3 , 7 5 \%}$ \\
\hline \multicolumn{2}{c}{ Media quality category } & Very Suitable \\
\hline
\end{tabular}

Based on the data obtained, it shows that the audio-visual stop motion video based on CTL in science learning, the water cycle material according to the media expert team is included in the interpretation criteria is very feasible, and can be tested in the learning process after revision is made according to criticism and suggestions from the media expert team. 
Table 6. Table of Material Expert Validation Assessment Results

\begin{tabular}{clcrc}
\hline \multirow{2}{*}{ No } & \multirow{2}{*}{ Assessment Aspects } & Expert Score Material I & Expert Score Material II & $\begin{array}{c}\text { NP (\%) } \\
\text { Total }\end{array}$ \\
\hline 1 & Content Feasibility Aspects & $91,67 \%$ & $93,75 \%$ & $92,71 \%$ \\
2 & Presentation Feasibility Aspects & $100 \%$ & $91,67 \%$ & $95,84 \%$ \\
3 & Contextual Assessment & $95,56 \%$ & $92,64 \%$ & $93,75 \%$ \\
\hline & & Mean & $\mathbf{9 4 , 0 5 \%}$ \\
\hline & \multirow{2}{*}{ Media quality category } & Very & Suitable \\
\hline
\end{tabular}

Based on the data obtained, it shows that the audio-visual stop motion video based on CTL in science learning material on the water cycle according to the material expert team is very feasible, and can be tested in the learning process after revisions are made according to criticism and suggestions from the material expert team.

Table 7. Table of Language expert Validation Results

\begin{tabular}{|c|c|c|}
\hline No & Language Expert & Score \\
\hline 1 & Language Expert I & $85,42 \%$ \\
\hline \multirow[t]{3}{*}{2} & Language Expert I & $84.03 \%$ \\
\hline & Mean & $84,72 \%$ \\
\hline & Media quality category & Very Suitable \\
\hline
\end{tabular}

Based on the data obtained, it shows that the audio-visual stop motion video based on CTL in science learning, water cycle material according to the language expert team is included in the interpretation criteria is very feasible, and can be tested in the learning process after a revision is made according to criticism and suggestions from the language expert team.

The fifth stage, product revision. Revisions were made by adjusting the criticism and suggestions that the researchers received from the expert team related to the shortcomings and weaknesses of CTLbased stop motion video media. The criticisms and suggestions from the validation expert team and the results of the improvements are as follows.

Table 8. Table of Inputs and Suggestions on Products by Validators

\begin{tabular}{|c|c|c|}
\hline $\begin{array}{l}\mathbf{N} \\
\mathbf{0}\end{array}$ & $\begin{array}{l}\text { Validat } \\
\text { or }\end{array}$ & Inputs and Suggestions \\
\hline \multirow[t]{4}{*}{1} & Media & a. In practicum activities, votes were given \\
\hline & Expert & b. Adding Pictures to the study guide scene \\
\hline & & $\begin{array}{l}\text { c. The illustration placement of pouring hot water and plain water is moved to after scene } \\
\text { instructions }\end{array}$ \\
\hline & & d. At the conclusion scene, the word "water cycle" is marked with an arrow \\
\hline \multirow[t]{3}{*}{2} & Materia & a. Adding voice/dubbing in the practicum section. \\
\hline & l Expert & $\begin{array}{l}\text { b. Show the practical illustration first before showing the illustration of the explanation of } \\
\text { the water cycle material itself so that the contextual role, especially constructivism, is } \\
\text { more striking. }\end{array}$ \\
\hline & & c. Add a list of references or references at the end of the video \\
\hline \multirow[t]{4}{*}{3} & $\begin{array}{l}\text { Langua } \\
\text { ge }\end{array}$ & $\begin{array}{l}\text { a. Improve the language used when dubbing into a more communicative language. } \\
\text { b. Narrate the procedures that will be carried out by students. }\end{array}$ \\
\hline & Expert & $\begin{array}{l}\text { c. Adding information related to the video that will be studied is a video for what grade } \\
\text { students are, the theme and sub-theme, and the learning to what. }\end{array}$ \\
\hline & & $\begin{array}{l}\text { d. Add motivationally and reinforcing sentences for students to continue studying at } \\
\text { home. }\end{array}$ \\
\hline & & $\begin{array}{l}\text { e. Correct sentences that still do not use capital letters at the beginning of the sentence } \\
\text { and a period at the end of the sentence. }\end{array}$ \\
\hline
\end{tabular}


Based on the input and suggestions from the expert team in table 8, the final CTL-based stop motion audio-visual video product is improved in the parts that have been suggested as follows.

\section{Before Revision}

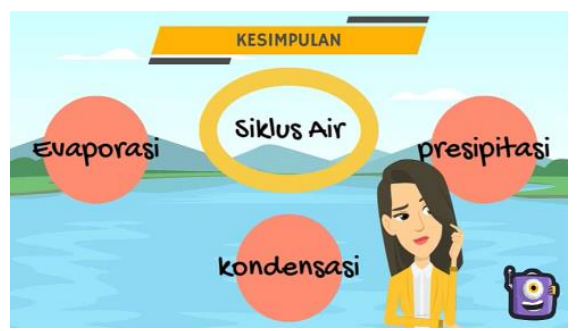

\section{Sesudah Revisi}

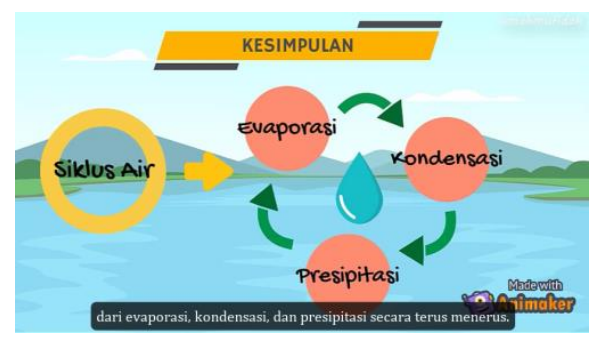

Figure 1. Sample of the revised product of media expert

The revision in Figure 1 is a sample from a list of inputs and suggestions provided by a team of media experts. Inputs and suggestions include (a) In the practicum activity, a voice is given, (b) Adding pictures to the learning instruction scene so that the visualization impression is maintained, (c) The placement of illustrations of pouring hot water and ordinary water is moved to after the instruction scene so that the impression of students can follow directions according to the instructions, (d) At the conclusion scene, the word: water cycle "is marked with an arrow so that it can be easily understood.

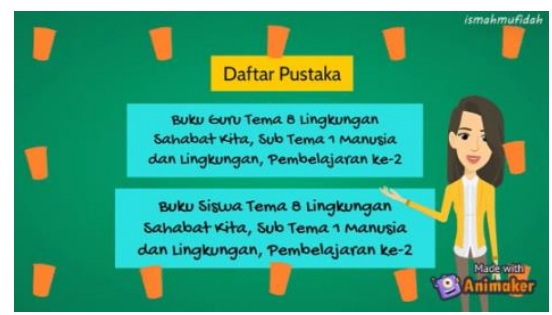

Figure 2. Samples of revised product material experts

The revision in Figure 2 is a sample from the list of inputs and suggestions provided by the material expert team. Inputs and suggestions include (a) Adding voice/dubbing in the practicum section, (b) Showing the practicum illustration first before showing the illustration of the water cycle material explanation itself so that the contextual role, especially constructivism, is more striking, (c) Adding a list of references or references in literature end of the video. 

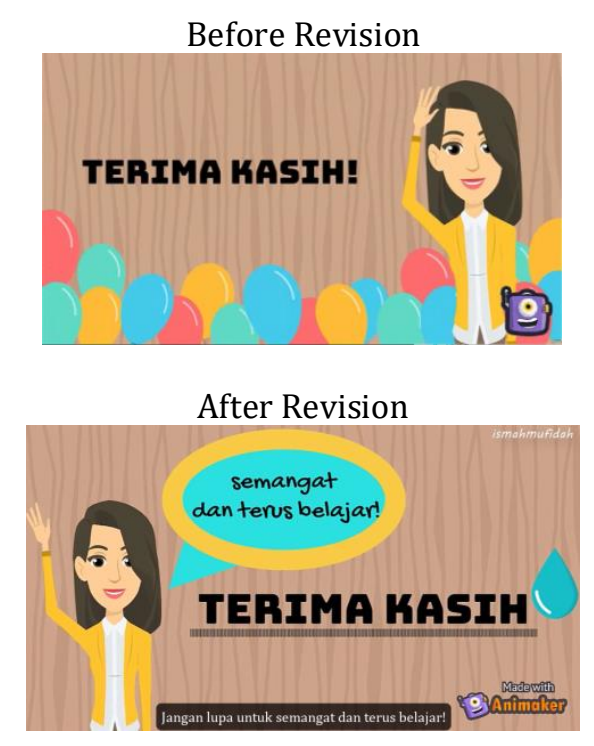

Figure 3. Language expert product revised sample

The revision in Figure 3 is a sample from the list of inputs and suggestions provided by the linguist team. Inputs and suggestions include (a) Improving the language used when dubbing into a more communicative language, (b) Narrating the procedures that will be carried out by students, (c) Adding information related to videos that will be studied is a video for what grade students are, the theme and sub-themes, as well as learning to what extent, (d) Adding motivational and reinforcing sentences for students to continue studying at home, (e) Fixing sentences that still do not use capital letters at the beginning of sentences and a full stop at the end of sentences.

The sixth stage, product testing. After a product revision was made on the stop motion video media based on CTL, the next step was conducting a product trial. This trial was conducted at SD Muhammadiyah Bojong Nangka with a sample of 15 students. At this stage, researchers conducted trials with an online system. Previously, this CTL-based stop motion video had been uploaded to the Youtube platform and the trial questionnaire was also transferred to Google Form. Students will see the video at their respective homes under the assistance of their parents or guardians during the learning process using CTL-based stop motion videos and during the process of filling out the questionnaire. CTL-based stop motion video media that have been tested are limited can be revised according to the results shown. rated by students. Then, the final result of this research and development is the product of stop motion video learning media based on CTL in science learning water cycle material for grade 5 elementary schools. This product is produced with. MP4 which can be displayed via smartphones and computer devices. The response of students to the CTL-based stop motion video media developed can be seen in the table of student response data analysis as follows.

Table 9. Table of Student Response Assessment Results

\begin{tabular}{clc}
\hline No & Assessment Aspects & Score \\
\hline 1 & Display Aspects & $91,67 \%$ \\
2 & Presentation Aspects of the Material & $93,33 \%$ \\
3 & Benefits Aspects $\quad$ Mean & $91,11 \%$ \\
\hline & \multicolumn{2}{c}{ M2,04\% } \\
\hline \multicolumn{2}{c}{ Categories of the quality of student responses } & Very good \\
\hline
\end{tabular}

Based on the data above, it was found that the validation results of 15 respondents on the display aspect were $91.67 \%$, the material presentation aspect was $93.33 \%$, and the benefit aspect was $91.11 \%$. Thus the average presentation of the results of the validation of students' responses to stop motion video learning media based on CTL was $92.04 \%$ with the criteria for the interpretation category "Very Good".

The development of instructional media in audio-visual stop motion video media products based on CTL uses development stages according to (Sugiyono, 2016) which explains there are 10 stages of development. However, due to limited costs and time, this study only uses 6 stages, namely problem 
analysis, data or information collection, product design, product validation, product revision, and product testing. In the first stage, this study conducted problem analysis in the form of curriculum analysis, needs analysis, and material analysis. The needs analysis was carried out by filling out a questionnaire with the informants, namely a grade V teacher at SD Muhammadiyah Bojong Nangka. According to the results of the questionnaire on July 20,2020, information was found that the learning media used in the water cycle material were pictured in student books and described the water cycle material on the blackboard. This makes students passive and teacher-centered learning. Meanwhile, the 2013 curriculum requires students to be active and teachers as facilitators. This is in line with the research that learning that is centered on students and teachers acting as facilitators can develop children's potential through problems that are of interest to children to be studied in the learning process (Suwarjo, 2012).

In the second stage, this research is continued with data collection. Data collection seeks to find what media can be a solution to the problems that have been found in the first stage, namely needs analysis. Therefore, this research intends to develop the two-dimensional image media before, into a collection of images which when put together will appear to move like a video, namely, stop motion video. Not only paying attention to video movements, but this development research also intends to display sound so that this media stimulates the senses of sight and hearing of students and displays something interesting from the media (Arsyad, 2014). The intended media development is to stop motion audiovisual media. One of the functions of audio-visual media is that audio-visual media can provide opportunities for students to learn independently, at a place and time, and their own pace Miarso in the journal (Hayati et al, 2017). That means, this audio-visual media is effective according to the demands of the 2013 curriculum and is flexible and can be used anytime, and by anyone. This media development also intends to make it easier for teachers to deliver learning material because it is easy to use and can be displayed on laptops, smartphones, or shared via public platforms such as YouTube.

This stop motion audio-visual video was developed to be used as a learning medium, especially the water cycle material in online learning which explains how something happened and does require visualization so that the material can be delivered more easily. In line with the research that students can use video media technology as a medium for finding information in learning (Hasibuan \& Prastowo, 2019). As already explained, stop motion is a technique of taking pictures using a camera and is taken by being photographed and then moved a little and then photographed again, so on, until the object looks as if it is moving. However, stop motion audio-visual video will be more meaningful if this video has the principles of learning written in Permendikbud Number 22 of 2016, one of which is that the participants are told to learn to find out. One of the lessons that approach these principles is contextual learning. This statement is in line with a study that with contextual learning, students will work and experience so that it is not just a transfer from teachers to students (Usmaedi, 2016).

After data collection, the third stage is carried out, namely designing research and development products. The first step taken was to determine the idea of making a stop motion audio-visual video based on CTL using a roughly drafted script. Starting with determining the basic competencies, indicators, and material limitations to be discussed so that the video duration is not too long. Then the script is transferred to a storyboard to make it easier to design the product. In the storyboard, some parts will appear in the CTL-based stop motion video, such as the opening part (producer identity, producer agency, material coverage, and perceptions including direct questions), content section (core learning activities include experiment and material explanation), and the closing part (evaluation questions, and words of motivation). The product that has been designed will be validated by three teams of experts at the fourth stage of this product development to find out its advantages and disadvantages. Among them are two lecturers as media experts, two lecturers as material experts, and two lecturers as language experts. The feasibility of the CTL-based stop motion audio-visual video media can be seen from the results of the product validation as a whole of $90.84 \%$ including the very feasible category, with the percentage of the validation results of the media team of $93.75 \%$, the percentage of the validation results of the material team is $94.05 \%$, and the percentage of the results of the language team validation was $84.72 \%$. According to the media expert team, the results of the validation obtained scores of 112 and 113 from a maximum score of 120 , with a percentage of $93.3 \%$ and $94.17 \%$. The score was not maximum from the media expert I of $6.7 \%$ because it had not yet reached the maximum score on the additional device, namely voice/dubbing. Meanwhile, the sub-optimal score of the media expert II was $5.8 \%$ because it was not sufficient to obtain a maximum score on the elements of layout, and the use of symbols and images. Based on the data obtained, it shows that the audio-visual stop motion video based on CTL in science learning, water cycle material according to the team of media experts is a very feasible interpretation criterion, and the CTL-based stop motion audio-visual video media can be tested in the learning process after it is done. 
revisions according to criticism and suggestions from the media expert team. The validation results according to the material expert team obtained a score of 130 and 126 from a maximum score of 136 , with a percentage of $95.50 \%$ and $92.60 \%$. The score is not maximum from the material expert I, which is $4.5 \%$ because it is not sufficient to get the maximum score on the list of references that are not included. Meanwhile, the score was not maximum from the material expert II of $7.4 \%$ because it was not sufficient to get a maximum score on the elements of adding sound instructions and video layout to suit contextual learning. Based on the data obtained, it shows that the audio-visual stop motion video based on CTL in science learning material on the water cycle according to the material expert team is very feasible, and the CTL-based audio-visual stop motion video can be tested in the learning process after revision is made. according to the criticism and suggestions from the material expert team. The validation results according to the team of linguists whom both got a score of 44 out of a maximum score of 52 with a percentage of $85.42 \%$ and $84.03 \%$. The difference in this percentage is due to the different scores of aspects in the language feasibility test between linguist I and linguist II. The score is not maximum from linguist I of $14.58 \%$ because it is not sufficient to get a maximum score on the suitability of punctuation and capital letters. Meanwhile, the non-maximal score of linguist II is $15.97 \%$ for language use when instructing, details on each instruction, information about videos, and motivational sentences that have not been added. Based on the data obtained, it shows that the audio-visual stop motion video based on CTL in science learning, according to the team of linguists, is a very feasible interpretation criterion, and the CTLbased stop motion audio-visual video can be tested in the learning process after revision. according to criticism and suggestions from the team of linguists.

The assessment of the feasibility of this CTL-based stop motion audio-visual learning video is in accordance with the characteristics of the learning video, namely (1) Clarity of message (message clarity, information received is more meaningful and complete), (2) Stand alone (stand-alone, does not require teaching materials other), (3) User friendly (easy to operate), (4) content representation (can be captured by the senses of students, then makes sense and is processed to get results, namely an idea/concept), (5) visualization with media (in it contains text, animation, and sound), (6) uses high-resolution quality, and (7) can be used classically and individually (can be used in class settings and at home) Cepi Riyana in the journal (Furi \& Mustaji, 2017).

Based on the characteristics of a good learning video, it can be seen from the results of expert validation. It can be shown by media experts that this media has user-friendly characteristics, visualization with media, high-resolution quality, and can be used classically and individually, which means that this media has visualization that involves students' senses of sight and hearing, has good video quality, is easy. operated so that it can be used flexibly anytime and anywhere, not necessarily in class settings. Then, the results of the material expert's validation show that this media has the characteristics of content representation and is stand-alone, which means that this media displays material that is easily captured by students and can stand alone without other teaching materials. Meanwhile, the results of the language validation indicate that this media has a clarity of message characteristic, which means that this media displays the clarity of the message, and information can be received completely related to the learning video. Based on the explanation above, the audio-visual stop motion video learning media based on CTL is said to be very suitable for use in elementary schools because it meets the characteristics of the learning video according to Cepi (Furi \& Mustaji, 2017).

Student responses to CTL-based stop motion audio-visual video media which were tested on Tuesday, July 212020 were conducted in class V at SD Muhammadiyah Bojong Nangka with 15 students as respondents. Limited trials were carried out online due to local government regulations that enforce school from home to minimize the spread of the Covid-19 virus. The limited trial technique uses stop motion audio-visual video uploaded to YouTube and assessment of student responses is carried out via Google Form. The video link and questionnaire that has been entered into the Google Form are distributed by the homeroom teacher. During the trial process limited to students, researchers were assisted by parents in guiding the learning process online. Students learn using instructional videos provided by researchers via the YouTube platform in parental guidance.

In the video, the initial part of the lesson, the core of learning, and the closing of the lesson are available so that the video can be used by students individually. This is in line with one of the characteristics of instructional videos, namely that videos can be used classically and individually, can be used in the classroom or at home Cepi Riyana in (Furi \& Mustaji, 2017). After using a CTL-based stop motion audio-visual video, students filled out a questionnaire to assess the response to the media used through Google Form. Based on the results of the assessment, the researcher divided the 11 positive and negative statements into 3 aspects, namely the display aspect with a percentage score of $91.67 \%$, the material presentation aspect with a percentage score of $93.33 \%$, and the benefit aspect with a percentage score of $91.11 \%$. Based on the results of the percentage of these three aspects, then an assessment of the 
audio-visual stop motion video media based on CTL obtained a percentage result with a total average of 92.04\% with the category of interpretation "Very Good".

From these results, the student response assessment shows that students give a very good response. This can be seen from the 3 aspects that are considered to be included in the very feasible interpretation category. Meanwhile, from the results of the development of CTL-based stop motion audiovisual media on the water cycle material that has been carried out, this video is included in interesting learning media so that students enjoy learning to use video while at home alone, motivating students in learning, making participants students independent with a little guidance from parents/tutors. This is in accordance with one of the benefits of learning media, namely that it can increase and direct children's attention so that it can foster learning motivation, more interaction between students and their surroundings, and the possibility of students to learn independently according to their abilities and interests (Arsyad, 2014).

Based on the explanation of the conclusions of the results of the research data calculation, the learning media audio-visual stop motion based on contextual teaching and learning developed has been deemed feasible to be used widely, so that it can make it easier for students to understand the material being taught. This research implies that in today's globalization era we are led to master technology. The use of audio-visual stop motion video learning media based on contextual teaching and learning can provide tremendous benefits, especially in the field of education. Situations and conditions that cause us not to close our eyes to keep up with the times. The use of the right technology will have implications for maximum results. So that the next generation is formed who are smart and responsible.

\section{Conclusion}

Research and development on CTL-based stop motion audio-visual media were carried out based on a modified research design by Sugiyono, but due to time and cost limitations, the research and development stages only reached the 6th stage, namely, (1) problem analysis, (2) data collection, (3) product design, (4) product design validation, (5) product revision and 6) limited product testing. The product produced from this research is in the form of audio-visual stop motion video learning media based on CTL for fifth-grade students of SD / MI in science learning water cycle material. The product developed has been validated and revised with the acquisition of an average validation value of the media expert team of $93.75 \%$ with the interpretation criteria "Very Appropriate", the average value of the validation team of material experts is $94.05 \%$ with the interpretation criteria "Very Appropriate", the average value of the validation team of linguists was $84.72 \%$ with the criteria for interpretation of "Very Appropriate". The stop motion audio-visual video based on CTL on the water cycle material that has been developed and is the final product has been tested on a limited basis on the fifth-grade students of SD Muhammadiyah, totaling 15 students with an average score of $92.04 \%$ student response with interpretation criteria " Very good". So, the learning media for audio-visual stop motion based on contextual teaching and learning that has been developed have been deemed feasible for widespread use.

\section{Reference}

Adi, A. P. (2017). Bikin Video Apapun Tanpa Ribet. Jakarta: PT. Elex Media Komputindo.

Arsyad, A. (2014). Media Pembelajaran. Jakarta: PT. Raja Grafindo Persada.

Asyhari, A dan Helda S. 2016. Pengembangan Media Pop-Up Book Untuk Pembelajaran Lingkungan Tempat Tinggalku Kelas IV SDN 1 Pakunden Kabupaten Ponorogo. Jurnal Ilmiah Pendidikan Fisika Al-BiRuNi, 5 (1), 1-13.

BSNP. (2008). Pedoman Penyusunan Kurikulum Tingkat Satuan Pendidikan Jenjang Sekolah Dasar. Jakarta: BSNP.

Fujiyanto, A., dkk. 2016. Penggunaan Media Audio Visual Untuk Meningkatkan Hasil Belajar Siswa Pada Materi Hubungan Antarmakhluk Hidup. Jurnal Pena Ilmiah, 1(1), 851-850. https://doi.org/10.23819/pi.v1i1.3576

Furi, U. L., Mustaji. (2017). Pengembangan Media Video Mata Pelajaran Komposisi Foto Digital Bagi Siswa Kelas XI Multimedia di Sekolah Menengah Kejuruan.Kwangsan, 5(2), 91-100. https://doi.org/10.31800/jtp.kw.v5n2.p91--100 
Hakiki, M., dkk. 2016. Pengaruh Model Pembelajaran Contextual Teaching And Learning (Ctl) Terhadap Hasil Belajar Teknologi Informasi Dan Komunikasi (Studi Kasus Kelas XII SMA Negeri 3 Padang). Jurnal bimbingan dan konseling, 1(2), 1-17. http://jurnal.umtapsel.ac.id/index.php/Ristekdik/article/view/62

Hasibuan, A. T., \& Prastowo, A. (2019). Konsep Pendidikan Abad 21: Kepemimpinan Dan Pengembangan Sumber Daya Manusia Sd/Mi. MAGISTRA: Media Pengembangan Ilmu Pendidikan Dasar Dan Keislaman, 10(1), 26-50. https://publikasiilmiah.unwahas.ac.id/index.php/MAGISTRA/article/download/2714/2676.

Hayati, N., Ahmad, M. Y., Harianto, F. (2017). Hubungan Penggunaan Media Pembelajaran Audio Visual dengan Minat Peserta Didik pada Pembelajaran Pendidikan Agama Islam di SMAN 1 Bangkinang Kota.Jurnal Al-hikmah, 14(2), 160-180. https://doi.org/10.25299/alhikmah:jaip.2017.vol14(2).1027

Kasmawati., dkk. 2017. Pengaruh Model Pembelajaran Contextual Teaching And Learning (CTL) Terhadap Hasil Belajar. Jurnal Pendidikan Fisika, 5(2), 70-75. http://journal.uinalauddin.ac.id/index.php/PendidikanFisika/article/viewFile/3482/3911

Kurniawan, C., dan Hidayati. 2019. Pengembangan Media Pembelajaran Siklus Air Dan Dampaknya Pada Tema Peristiwa Dalam Kehidupan Untuk Kelas V SDN Jetis II. Trihayu: Jurnal Pendidikan Ke-SD-an, 5 (2), 611-615.

Lailatusholihah, I., S. K. 2016. Pengembangan Stop Motion Chemistry Sebagai Media Pembelajaran Audio Visual Materi Laju Reaksi Untuk Peserta Didik SMA/MA. Jurnal Pembelajaran Kimia, 5(3), 1-11.

Lisiswanti, R., dkk. 2016. Peranan Media Dalam Pembelajaran. Jurnal Kesehatan, 6 (1), 102-105. http://ejurnal.poltekkes-tjk.ac.id/index.php/JK/article/viewFile/37/31

Maryanti, S., Kurniawan, D. T. (2017). Pengembangan Media Pembelajaran Video Animasi Stop motion untuk Pembelajaran Biologi dengan Aplikasi Picpac. E- Jurnal Program Studi Pendidikan Biologi, 8(1) 26-33. https://doi.org/10.15575/bioeduin.v8i1.2922

Musriliani, C., dkk. 2015. Pengaruh Pembelajaran Cotextual Teaching Learning terhadap Kemampuan Koneksi Matematis Siswa SMP Ditinjau dari Gender. Jurnal Didaktik Matematika, 2(2), 49-58. http://www.jurnal.unsyiah.ac.id/DM/article/view/2814

Pradilasari, dkk. 2019. Pengembangan Media Pembelajaran Berbasis Audio Visual pada Materi Koloid Untuk Meningkatkan Motivasi dan Hasil Belajar Siswa SMA. Jurnal Pendidikan Sains Indonesia (Indonesian Journal of Science Education), 7(1), 9-15. https://doi.org/10.24815/jpsi.v7i1.13293

Purwanti, R., dan Natanael R. 2016. Video Animasi Stop Motion Sebagai Media Pembelajaran Pada Kampanye Pengenalan Tertib Berlalu Lintas Bagi Remaja Pengendara Sepeda Moto. Widyakala, 3, 1-8. https://doi.org/10.36262/widyakala.v3i0.19

Purwanto. (2014). Evaluasi hasil Belajar. Yogyakarta: Pustaka Pelajar.

Purwono, dkk. 2014. Penggunaan Media Audio-Visual Pada Mata Pelajaran Ilmu Pengetahuan Alam Di Sekolah Menengah Pertama Negeri 1 Pacitan. Jurnal Teknologi Pendidikan dan Pembelajaran, 2(2), 127-144. https://core.ac.uk/download/pdf/289791698.pdf

Ridwan, A. (2015). Rumus dan Data Dalam Analisis Statistika Untuk Penelitian. Bandung: Alfabeta.

Rozie, F. 2013. Pengembangan Media Video Pembelajaran Daur Air untuk Meningkatkan Proses dan Hasil Belajar IPA Siswa SD. Jurnal Pendidikan Sains, 1(4), 413-424. http://dx.doi.org/10.17977/jps.v1i4.4191

Sabroni, D. 2017. Pengaruh Model Pembelajaran Contextual Teaching And Learning (CTL) Terhadap Kemampuan Komunikasi Matematis Siswa. Seminar Nasional Matematika dan Pendidikan Matematika, 1(1), 56-68. https://proceedings.radenintan.ac.id/index.php/pspm/article/view/21

Sari, P. M. N., dkk. 2020. Efektivitas Hasil Belajar Matematika Melalui Model CTL Berbasis Masalah Terbuka Siswa Kelas IV SD. Jurnal Ilmiah Sekolah Dasar, 4(2), 248-256. http://dx.doi.org/10.23887/jisd.v4i2.25558

Sugiyono. (2016). Metode Penelitian Kuantitatif, Kualitatifdan R\&D. Bandung: Alfabeta. 
Sulfemi, W. B. dan Nunung Y. 2019. Model Pembelajaran Contextual Teaching And Learning (CTL) Berbantu Media Miniatur Lingkungan Untuk Meningkatkan Hasil Belajar IPS. Jurnal Ilmiah Pendidikan Ekonomi Fakultas Keguruan dan Ilmu Pendidikan, 7(2), 73-84. http://dx.doi.org/10.33603/ejpe.v7i2.1970

Suwarjo. (2012). Penerapan Student Centered Approach pada Pembelajaran Taman Kanak-Kanak Kelompok B (Studi Kasus di Sekolah Laboratorium Rumah Citta). Jurnal Pendidikan Anak 1(1), 79102. https://doi.org/10.21831/jpa.v1i1.2924

Usmaedi., Alamsyah, T. P. (2016). Penerapan Metode Pembelajaran Contextual Teaching Learning (CTL) Terhadap Hasil Belajar dan Self-Esteem Siswa Sekolah Dasar Pada Mata Pelajaran Pendidikan $\begin{array}{llll}\text { Pancasila Dan } \quad \text { Kewarganegaraan (PKn). JPSD, 215-223. } & \text { 2(2), }\end{array}$ http://dx.doi.org/10.30870/jpsd.v2i2.800 